\title{
НАЦІОНАЛЬНА ЕКОНОМІКА
}

\author{
UDC 330.131.7:658 \\ DOI: https://doi.org/10.32782/2415-8801/2019-5.1
}

Baranovska Sofiya

PhD Doctor,

Associate Professor of the Department of Accounting and Analysis, Lviv Polytechnic National University

Tesak Oleksandra

PhD Doctor,

Associate Professor of the Department of Accounting and Analysis, Lviv Polytechnic National University

\section{COMPETITIVENESS OF THE ENTERPRISE: MANAGEMENT, ANALYSIS, PROSPECTS}

We have examined the theoretical foundations of the competitiveness of Ukrainian enterprises. We have justified conceptions of strategic orientation of the enterprise competitiveness management, implementation of which requires not only theoretical, methodological, and methodical support but also analysis of external and internal socio-economic relations in accordance with current trends. The process of enterprise competitiveness management is considered as a chain of continuous and interrelated acts - management functions united by communications. Regarding the process of quick and appropriate response to changes in the environment in the context of intellectual factor importance, in the days of the global financial crisis, many Ukrainian enterprises showed unpreparedness for the competitive struggle over the lack of response to changes in the internal and external environment. Enterprise competitiveness management is considered as a chain of continuous and interrelated acts - management functions united by communications.

Keywords: competitiveness, enterprise management system, management functions, management system diagnostics, competitive environment, enterprise potential.

\section{КОНКУРЕНТОСПРОМОЖНІСТЬ ПІДПРИЕМСТВА: УПРАВЛІННЯ, АНАЛІЗ, ПЕРСПЕКТИВИ}

Барановська С.П., Тесак О.В.

В статті розглядається конкурентоспроможність як одна з основних складових успіху підприємства. Загальний рівень конкурентоспроможності краӥни в цілому, і будь-якого підприємства, зокрема, може покрацуватись тільки за допомогою реформ у різних сферах. Для розвитку конкурентного потенціалу, Украӥні слід використовувати головні переваги, цо вирізняють ї̈ при порівнянні з аналогічними краӥнами: розмір внутрішнього ринку, освіченість населення, здатність до інновацій. Підвищення конкурентоспроможності крайни залежить не тільки від успішності державних реформ, суспільних установ, політичної ситуації, інфраструктури й економічного середовища, але й від реалізації конкурентоспроможного потенціалу промислових підприємств краӥни. Конкурентоспроможність підприємства є комплексною та багатогранною категорією, яка відображає сукупність порівняльних переваг у різних сферах (економічній, кадровій, товарній, ринковій тощо), поєднання яких формус для підприсмства більи стійкі позицї на певному ринку у відповідний період часу у порівнянні з визначеними конкурентами. Основною проблемою сьогодення, яка постає перед підприємствами - це проблема формування стійких конкурентних переваг через цілковите взаємоузгодження можсливостей підприємств з внутрішнім потенціалом та нереалізованими резервами 3 метою максимальної продуктивності роботи підприємств на ринку. Механізм управління конкурентоспроможністю підприємства базується на технічних, економічних, соціальних, психологічних, правових, комерційних, організаційних аспектах. Вони, хоч і с складовими однісї ланки забезпечення конкурентоспроможності продукції та підприсмства в цілому, але функціонують у певній послідовності відповідно до ӥх важсливості. Для ивидкої та адекватної реакцї̈ на зміни середовица та в умовах ваэжльості інтелектуального фактору, під час світової фінансової кризи, багато підприємств Украӥни виявили неготовність до конкурентної боротьби через відсутність реакції на зміни зовнішнього та внутрішнього середовищ. Незважаючи на підвищення інтересу до управління конкурентоспроможнністю промислових підприємств, економічна наука і господарська практика не мають відповідей на цілий ряд наукових та прикладних питань. Тому проведені дослідження були спрямовані на вирішення ваэливої наукової проблеми обтрунтування сутності діагностики системи управління підприємством через вплив конкурентоспроможності та використання певного інструментарію.

Ключові слова: конкурентоспроможність, система управління підприємством, функиії управління, діагностика системи управління, конкурентне середовище, потенціал підприємства. 


\section{КОНКУРЕНТОСПОСОБНОСТЬ ПРЕДПРИЯТИЯ: УПРАВЛЕНИЕ, АНАЛИЗ, ПЕРСПЕКТИВЫ}

Барановская С.П., Тесак А.В.

Рассмотрены теоретические основы конкурентоспособности украинских предприятий, обоснованно концепции стратегической ориентации управления конкурентоспособностью предприятия, реализация которой требует не только теоретического, методологического и методического обеспечения, но и в соответствии с современными тенденциями, анализа внешних и внутренних социально-экономических отночений. Управление конкурентоспособностью предприятия рассматривается как цепь непрерывных и взаимосвязанных действий функций управления, объединенных между собой коммуникациями. Процесс быстрой и адекватной реакции на изменения среды и в условиях важннсти интеллектуального фактора, во время мирового финансового кризиса, многие предприятия Украины обнаружили неготовность к конкурентной борьбе за отсутствия реакции на изменения внешней и внутренней среды.

Ключевые слова: конкурентоспособность, система управления предприятием, функции управления, диагностика системы управления, конкурентная среда, потенциал предприятия.

Problem statement. The notion of competitiveness has become an object of contradiction in modern economy of Ukraine as well as in global economy in general. Although national economic studies did not give due attention to the given problem, making reference to comparison of product characteristics with world analogues and their meeting the world's requirements, many academic specialists performed analysis from a different angle. Currently, the state of the Ukrainian economy makes it clear that it is expedient and relevant to promote research of the mechanisms of influence on improving competitiveness of enterprises.

Recent research and publications analysis. The following national academic specialists made certain contribution into theoretical advances in the field of competition, paradigms of managing modern development: A. Halchynskyi, A. Pavlova, M. Skrypnychenko [2], V. Bodrov, V. Heits, O. Yaremenko, V. Sidenko, O. Dmytrenko. They draw attention to the following aspects: changing nature of resource potential; ensuring competitiveness of markets is becoming more complicated; transition of macroeconomic regularities to probability form; growth of institutional gap between real and financial sectors, that leads to substantial adjustments in the basic determinants of the enterprise competitiveness.

A. Voronkova points out that competitiveness is a special feature of a market entity, manifested in the course of competition and allowing it to fill a specific market niche in the market economy with a view to ensuring reproduction on a large scale, which foresees covering of all expenses of production and making a profit from business activity. Therefore, competitiveness of an enterprise makes up a generalized outcome indicator of its steady performance, which includes operating results of a variety of production, additional and managerial subdivisions, subsystems and attracted resources [1].

Among academic specialists researching the issues of competitiveness there is a belief of systemic improvement of competitive environment, taking away possibilities of receiving opaque competitive advantages, advantages of asymmetric behavior etc. This will be encouraged by active antimonopoly policy, anti-corruption enforcement, the highest possible transparency of access to government aid, incentives and public purchases, leading to the higher interest of business in public participation ensuring favourable state policy formation [2].

In the course of enterprise competitiveness assessment, one should also assess economic strength of the given enterprise. Such issues were investigated by a lot of national and foreign academic specialists, among them L. Koval, S. Kotyrieva, N. Krasnokutska, T. Lepeiko and others. The notion of enterprise competitiveness and the state of its economic potential are inextricably linked in the system of strategic management with its internal processes. Thus, assessing the enterprise economic potential, it is also necessary to assess the level of its competitiveness.

However, ambiguity of conceptual approaches towards interpretation of the notion of competitiveness itself, insufficient study of methodological and applied questions regarding formation and management of the enterprise potential competitiveness require deeper research activity in this field.

Research objective. The goal of the given article is the investigation of the essence of competitiveness of the enterprise potential, main components and ways of its improvement in current market environment. The article aims at analyzing functions of managing competitiveness that may be influential within general tasks of the enterprise management system as a whole.

Presentation of basic material of the research. During the past decade market transformations in Ukraine are determining the changes in the enterprise management system appropriate for the external competitive environment. Enterprise competitiveness as an object of management is a set of interrelated elements focused on ensuring strong competitive positions, support of current competitive advantages as well as creation of the new ones. Approaching the high level of competitiveness is a strategic goal of enterprise performance in the market economy conditions for the achievement of which it is necessary to consolidate all subdivisions and sectors of the enterprise management system.

Enterprise competitiveness is a complex and multifaceted category reflecting a total of comparative advantages in various spheres (economic, personnel, commoditybased, market-based etc.), the combination of which forms more stable positions of the enterprise on a particular market at the relevant time as compared with certain competitors. Enterprise competitiveness is formed through effective use of production, marketing, financial, personnel, and property potential as well as through flexible adaption to the changes of business environment, and often - through being ahead of these changes.

The notion of competitiveness includes a wide complex of economic, legal and other characteristic features deter- 
mining the position of the enterprise on sectoral, regional or world market. The above mentioned complex may include product specifications based on production field as well as factors that generally form economic conditions for production and sales. The level of the enterprise competitiveness is a mirror reflecting total performance outcomes of practically all the enterprise services as well as the state of external environment [3].

For successful management of competitiveness it is necessary to study the market, correctly assess one's own competitiveness, possibilities of competitors and factors determining them. Modern mechanism of competitiveness management is becoming one of the most important enterprise tasks to be completed, and it is difficult to survive on the competitive market and achieve the desired effect of one's own performance without completing it.

Highly competitive market environment has caused the relevant formation of approaches towards the enterprise competitiveness management. The process of competitiveness formation is complex and involves the elements of both internal and external environment. It is significant to define factors influencing the management of competitiveness.

The mechanism of the enterprise competitiveness management is a total of means and methods that help to influence the whole available internal enterprise potential and controlled parameters of external environment, taking into account market situation tendencies, for the sake of achieving the desired level of competitiveness.

It is necessary to carry out diagnostics and monitoring of competitive potential on a regular basis, which ensures obtaining information about the state and possible ways of the most efficient use of potential over time as well as determines not only directions, but also possibilities of implementing competitive strategies [4].

The enterprise competitiveness depends significantly on the following factors that form competitive environment: competitiveness of the sector, performance region and economy of Ukraine in general. The last one, in its turn, determines the terms, interaction and nature of competition among business entities [5].

The enterprise competences are an integral part of strategic assets, reflecting a complex of collective knowledge, experience and capabilities of the enterprise, which together with unique technology allows creating competitive advantages and ensuring distinguishing features of the enterprise within certain market environment. Therefore, a certain cause and effect relationship between key market factors of success, asset base and competences of competitive advantages may be traced [6].

Management of the enterprise competitiveness is a certain aspect of the enterprise management focused on formation, development and implementation of competitive advantages as well as ensuring the enterprise functioning as an entity of economic competition. Modern conception of the enterprise competitiveness management is based on the usage of fundamental statements of the management science, according to which the main elements of the management system are the following: aim, object and subject, process and functions of management.

The aim of the enterprise competitiveness management is to ensure functioning and smooth operation of the enterprise under any economic, political, social and other changes in its external environment.
The object of the enterprise competitiveness management is the level of competitiveness necessary and sufficient for ensuring functioning of the enterprise as an economic competition entity. The subjects of competitiveness management include a certain scope of persons accomplishing its goal.

From the perspective of process approach, the enterprise competitiveness management is a process of implementing a certain set of managerial functions - goal-setting, planning, administration, motivation and control of activities on forming competitive advantages and ensuring functioning of the enterprise as an economic entity.

World Economic Forum published the results of the annual Global competitiveness report in 2018. Ukraine was ranked 83 among 140 rating participants (scoring 57 points out of 100 possible). In 2017 Ukraine was ranked 89 among 135 participants. However, the changes in the ranking methodology do not allow us to make direct comparison of the Ukrainian position to the last year's ranking.

World Economic Forum has changed the calculation methodology of the annual Global competitiveness ranking. New methodology covers 140 countries, competitiveness of which is assessed based on 98 indicators grouped into 12 basic components - performance drivers, forming the country's competitiveness. Developing team working on the methodology set a goal of tracing macroeconomic dynamics to the fullest extent under the conditions of the Forth Industrial Revolution, and concentrate on new competitive factors associated with rapid digitalisation that earlier was not a priority of governmental political decisions. We are referring to the generation of ideas, entrepreneurial culture, innovations, transparency and flexibility. Therefore, new Global Competitiveness Index 4.0 has, just as in the past year, 12 components, though the components themselves were reorganized and obtained new names. The number of indicators went down from 114 to 98, and 64 indicators are new. The indicators themselves were calculated based on statistics and polling. According to the new methodology, Ukraine was ranked 83 among 140 countries. As a matter of form, the position of Ukraine improved by 6 positions. The change of methodology does not allow us to make direct comparison of the Ukrainian position to the last year's ranking. However, in order to compare indicators' dynamics, the developers of the ranking also calculated the countries' positions based on the data obtained from the previous period. Thus, we can trace annual changes in a given "new" indicator and component forming the general rating of the country in 2018. The result is that according to the new methodology compared to the previous year, the positions of Ukraine declined as far as 11 components are concerned, and only one component ("Business dynamics") shows an upward trend. Ukraine got the highest score for the following components:

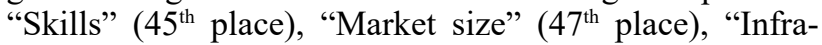

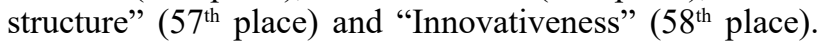
Moreover, as far as "Electrification level" indicator is concerned, Ukraine even managed to score the first place. However, Ukraine shared that first place with 66 other countries being ranked.

The following components weigh Ukraine down: "Macroeconomic stability" (131 $1^{\text {st }}$ place), "Financial system" (117 $7^{\text {th }}$ place $)$, and "Institutions" $\left(110^{\text {th }}\right.$ place $)$. Among the indicators providing low scores to Ukraine are the following ones: 
- The effect of organized criminal activity on the cost of doing business;

- Inflation rate (an average rate for 2016-2017);

- Dynamics of debt with consideration to the credit rating of the country;

- Terrorism level;

- Judicial independence;

- Property rights protection;

- Quality of roads;

- The effect of taxes and subsidies on competition;

- Flexibility of wage determination;

- Financing for small and medium-size businesses;

- Banking soundness;

- Participation in problem loan;

- Rate of growth of innovative companies [7].

Such an analysis of the country competitiveness provides us with the general assessment of the state of business activity within a country. As the result of searching for the best combination of goals and functional management structures, new structural forms of the enterprise management appear. Investigation carried out by the management specialists have shown that efficient organization is based on seven related components that change of each other. The basic ones are the following:

- A strategy - plans and directions for action defining resource allocation, fixing obligations for carrying out specific actions in time for the achievement of certain goals;

- A structure - internal organization arrangement reflecting its subdivision into departments, hierarchical subordination of these departments, distribution of power among them;

- Systems - procedures and everyday issues arising within an organization;

- Staff - important personnel groups existing within an organization characterized in terms of age, gender, educational level, etc;

- A style - a method used by the directors to manage an organization; here belongs corporate culture as well;

- Qualification - special abilities of key people within an organization;

- Shared values - the content of the core directions of activity that an organization brings to its members' attention [8].

Analyzing the idea of competitiveness, five types of competitive advantages may be singled out: resource-related competitive advantages of companies associated with price characteristics of products bought for business operation; technological - competitive advantages of manufacturers associated with operational use of technologies that allows applying production scale effect; innovative - competitive advantages associated with qualitative parameters of produc- tion; global - competitive advantages of manufacturers that have determined and comply with the standards of general humanitarian business activity, and are implemented by the united actions of companies and the state; cultural - competitive advantages of manufacturers conditioned by historical and cultural relations of countries that allow the companies to hold market outlets and resources [9].

It may be defined that strategic management of competitiveness is a complex process of concept-based vision as well as practical formation, implementation and enhancement of the system of competitive advantages, including strategic analysis, concept generation, strategy development, planning and organization of its implementation, regulation following controlling results. Although each of the above mentioned elements is significant, the defining role belongs to strategic planning and the choice of strategic model of competitiveness formation [10].

As far as the enterprise competitive growth is concerned, attention must be paid to the development of efficient management system, reconstruction strategy and improving competitiveness of production operation and products. One of the efficient means of ensuring enterprise competitiveness and stability is flexibility of production systems, adaptability to changes in operational behavior at lower cost or free of expenses. Searching consumers and development of new products themselves cannot preserve competitive advantages and the enterprise stability if the quality of manufacture does not meet the world standards.

Under current conditions of economic management, competitive struggle is one of the main enterprise tasks. Besides, there is a constant process of developing manufacture means and methods resulting in even larger competition. Therefore, every enterprise has to be concerned about its competitiveness.

Conclusions. Competitiveness as a category in modern economic society plays a universal role. Accordingly, the level of economic and social growth depends significantly on this notion. The mechanism of managing the enterprise competitiveness is based on technical, economic, social, psychological, legal, commercial, and organizational aspects. And even though they belong to the same segment of promoting production and enterprise competitiveness in general, they are functioning in a fixed sequence in accordance with their significance. The role of the state cannot be neglected as well, as it should promote creation and support of conditions for perfect competition. Competitive positions of the enterprise on the market depend on the support and assistance received by the enterprise from national public authorities as well as on efficient and justified state policy.

1. Voronkova A E., Kaliuzhna N.H., Olenko V.I. (2008). Upravlinski rishennia vzabezpechenni konkurentospromozhnosti pidpryiemstva: orhanizatsiynyi aspekt: monohrafia [Managerial decisions in ensuring the enterprise competitiveness: organizational aspect: monograph]. Kharkiv: INZHEK. 512 p.

2. Skrypnychenko M.I., Doctor of Economics (ed.) (2018). Chynnyky i trendy ekonomichnoho rozvytku v Ukraini: kolektyvna monohrafia [Factors and trends of economic development in Ukraine: joint monograph]. NAS of Ukraine, State Organization "Institute of the Economy and Forecasting of the National Academy of Sciences of Ukraine". Electronic message. Kyiv, 386 p.

3. Yankovyi O.H. (ed.) (2013). Konkurentospromozhnist pidpryiemstva: otsinka rivnia ta napriamy pidvyshchennia: monohrafiia [The enterprise competitiveness: assessing the level and directions for improvement: monograph]. Odesa: Atlant, $470 \mathrm{p}$.

4. Sharko M.V. (ed.) (2016). Upravlinnya konkurentospromozhnistiu pidpryiemstv u suchasnykh umovakh: kolektyvna monohrafiia [Management of the enterprise competitiveness under current conditions: joint monograph]. Kherson : PP Vyshemyrskyi V.S., 177 p. 
5. Kuzmin O.Y., (ed.), Melnyk O.H., Romanko O.P. (2011). Konkurentospromozhnist pidpryiemstva: planuvannia ta diahnostyka: monohrafiia [The enterprise competitiveness: planning and diagnostics: monograph]. Ivano-Frankivs'k: IFNTUNH, $180 \mathrm{p}$.

6. Nitsenko V.S. (ed.), Zakharchenko O.V. (ed.), Zaiets M.A. (ed.), Havrysh V.I., Yatsenko O.M., Perebyinis V. I. and others (2015). Konkurentnospromozhnist pidpryiemstv v umovakh rynkovoi ekonomiky: u 3-kh tomakh. Tom 2: teoretykometodolohichni osnovy konkurentospromozhnosti: monohrafiia [Competitiveness of enterprises under the market conditions: in 3 volumes: Volume 2: theoretical and methodological background to competitiveness: monograph]. Odesa: VMV. 174 p.

7. Global Competitiveness Ranking 2018: How to Improve Positions Despite the Fall / CASE Ukraine Center for Social and Economic Research. URL: http://case-ukraine.com.ua/news/globalnij-rejting-konkurentospromozhnosti2018-yak-pokrashhiti-pozitsiyi-nezvazhayuchi-na-padinnya/ (accessed 17 October 2019).

8. Hanchenko O.Y. (2007). Korporatyvna konkurentospromozhnist ta problemy yii otsiniuvannia [Corporate competitiveness and problems of its assessment]. Problemy ekonomiky ta upravlinnia, no. 579, pp. 384-387.

9. Skrypnychenko M.I., Heiets V.M., Prykhodko T.I. (2003). Transformatsiyni protsesy ta ekonomichne zrostannia $v$ Ukraini: monohrafiia [Transformational processes and economic growth in Ukraine: monograph]. Institute of the Economic Forecasting. Kharkiv: Fort, 437 p.

10. Miklovda V.P., Britchenko I.H., Kubiniy N.Yu., Kolodynskyi S.B., Tsitsak L.M. (2012) Stratehichne upravlinnia konkurentospromozhnistiu: epistomolohichni pidkhody ta praktyka, problematyka: monohrafia [Strategic management of competitiveness: epistemological approaches and practice, problematics: monograph]. Poltava, 297 p.

1. Воронкова А.Е., Калюжна Н.Г., Оленко В.І. Управлінські рішення в забезпеченні конкурентоспроможності підприсмства: організаційний аспект : монографія. Харків : ІНЖЕК, 2008. С. 512.

2. Скрипниченко М.I. Чинники і тренди економічного зростання в Україні : колективна монографія / за ред. д-ра екон. наук М.І. Скрипниченко; НАН Украӥни, ДУ «Ін-т екон. та прогнозув. НАН Украӥни». Київ, 2018. С. 386.

3. Янковий О.Г. Конкурентоспроможність підприємства: оцінка рівня та напрями підвищення: [монографія / за заг. ред. О.Г. Янкового]. Одеса : Атлант, 2013. С. 470.

4. Шарко М.В. Управління конкурентоспроможністю підприємств у сучасних умовах: колективна монографія / за заг. ред. д.е.н., проф. Шарко М.В. Херсон : ПП Вишемирський В.С., 2016. С. 177.

5. Кузьмін О.С. Конкурентоспроможність підприємства: планування та діагностика : монографія / О.С. Кузьмін, О.Г. Мельник, О.П. Романко; за заг. ред. д.е.н., проф. Кузьміна О.С. Івано-Франківськ : ІФНТУНГ, 2011. С. 180.

6. Конкурентоспроможність підприємств в умовах ринкової економіки: у 3-х томах: Том 2: Теоретико-методологічні основи конкурентоспроможності: [монографія] / [В.І. Гавриш, О.М. Яиенко, В.І. Перебийніс, ін.] за заг. ред. В.С. Ніценка, О.В. Захарченка, М.А. Зайия. Одеса: ВМВ, 2015. С. 174.

7. Глобальний рейтинг конкурентоспроможності 2018: як покращчити позищії, незважсаюи на падіння / Центр соиіально-економічних досліджень CASE Україна. URL: http://case-ukraine.com.ua/news/globalnij-rejtingkonkurentospromozhnosti-2018-yak-pokrashhiti-pozitsiyi-nezvazhayuchi-na-padinnya/ (дата звернення 17.10.2018).

8. Ганченко О.Я. Корпоративна конкурентоспроможність та проблеми ї̈ оцінювання. Проблеми економіки та управління. 2007. № 579. С. 384-387.

9. Скрипниченко М.I., Геєц̧ь В.М., Приходько Т.I. Трансформаційні процеси та економічне зростання в Україні : монографія. Інститут економічного прогнозування. Харків : Форт, 2003. С. 437.

10. Мікловда В.П., Брітченко І.Г., Кубіній Н.Ю., Колодинський С.Б., Ціцак Л.М. Стратегічне управління конкурентоспроможністю: епістомологічні підходи та практика проблематика : монографія. Полтава, 2012. С. 297.

E-mail: oleksandra_av@ukr.net 